\title{
The Osteogenetic Potential of Chitosan Coated Implant: An In Vitro Study
}

\author{
Alnufaiy BM ${ }^{1}$, Lambarte RNA ${ }^{2}$, Al-Hamdan $\mathrm{KS}^{3}$
}

\begin{abstract}
Objective: Chitosan is a promising polymer that has been used for coating dental implants. However, research concerning coatings with implant surfaces other than commercially pure titanium is limited. Therefore, this study aims to clarify the chitosan material's effect with two degrees of deacetylation (DDA) as coatings for laser surface microtopographic implants. Methods: Sixty-three Laser-Lok (LL) implant discs were divided into three groups (21 in each group), and two groups were coated with either 80 or 95 DDA chitosan. The groups were categorized as LL 95, LL 80, or LL control. Then, hMSC-TERT 20 cells were used to evaluate the cell morphology, viability, and osteogenic capacity of the chitosan material 7 and 14 days after culture. Two-way ANOVA followed by one-way analysis of variance (ANOVA) and Tukey's post hoc test were used. Results: All samples were biocompatible and allowed cell attachment. However, cell spreading and attachment were noticeably increased in the LL 95 group. There was a significant increase in the expression of osteogenic markers in chitosan-coated samples compared to the control group. The 95 DDA-coated group exhibited higher ALP, Runx2, osteocalcin, and osteonectin expression compared to the 80 DDA and control groups on days 7 and 14. Conclusion: A high DDA of chitosan promotes biomineralization and osteoblast formation. Therefore, this combination of laser surface and chitosan can enhance future dental implant healing processes and osseointegration.
\end{abstract}

Key Words: Chitosan; Implant coating; Laser lock

\section{Introduction}

The osseointegration process is critical because many factors influence the formation and maintenance of bone that comes in contact with the surface of an implant ${ }^{[1,2]}$. Enhanced implant surface technology has been developed to improve the rate of predictability and degree of osseointegration. Therefore, implant surfaces have been modified using additive or subtractive techniques ${ }^{[3,4]}$.

Implant surface modifications, including chemical and topographical characteristics, were implemented to improve the predictability of the clinical outcome ${ }^{[5,6]}$. Laser-Lok (LL) microchannels include a range of accurate, cell-sized engineered channels laser-etched onto dental implants. Therefore, this unique nanoscale technique has been reported to enhance both connective tissue attachment and hard tissue integration ${ }^{[7,8]}$. Chitosan, a natural biocompatible polymer, has been extensively used as a pharmaceutical component extracted by the partial deacetylation of chitin, the second most abundant natural polymer ${ }^{[9]}$. This polymer varies in its degree of deacetylation (DDA), viscosity, and molecular weight ${ }^{[10]}$. It exhibits a promising range of biomedical applications for addressing implant coating, wound dressings, tissue engineering, and therapeutic agent delivery systems ${ }^{[11,12]}$.

Chitosan is a biocompatible, biodegradable, osteoconductive, and excellent wound healing accelerator with anti-inflammatory properties $^{[13,14]}$. Because of these properties, chitosan has been investigated as a coating for implant materials to promote osseointegration in vitro and in vivo ${ }^{[15,16]}$.
Given the promising results of chitosan for engineering and implant applications ${ }^{[13]}$, its performance and capabilities need to be further developed for bone. There is a gap concerning the actions of chitosan with different degrees of deacetylation (DDA), which can react with different implant surfaces. Previous studies have generally been centered on the use of commercially pure titanium. Therefore, this study aims to examine the effects of chitosan with two degrees of deacetylation (DDA) as a coating for laser ablation implant surfaces.

\section{Materials and Methods}

\section{Research Design}

The study used a randomized controlled trial design to examine the effects of chitosan with two degrees of deacetylation (DDA) as a coating for the Laser-Lok surface.

\section{Materials}

Chitosan powders with 80 and 95 DDA (200 kDa molecular mass and $500 \mathrm{mPa} \cdot \mathrm{s}$ viscosity) were used (Heppe Medical Chitosan, Germany). The study utilized 63 Laser-lock (LL) discs (BioHorizon Company, USA) with a diameter of $10 \mathrm{~mm}$. The discs were divided into three groups of 21 discs for each (LL 95, LL 80, and LL control).

\section{Chitosan Bound to the Implant Disc}

A chemical salinization reaction according to the Bumgardiner methodology with some modifications was used for coating the discs with chitosan ${ }^{[17]}$. The disc was suspended in a stirred 5:95 
vol\% water/ethanol solution that was acidified to $4.5 \mathrm{pH}$ with $10 \mathrm{M}$ acetic acid. Subsequently, the saline coupling agent ( $2 \mathrm{vol} \%)$ was added over $10 \mathrm{~min}$ at room temperature (RT) while the $\mathrm{pH}$ was maintained between $4.5-5.5$ with $1 \mathrm{M} \mathrm{NaOH}$ or $10 \mathrm{M}$ acetic acid. After that, the discs were washed using ethanol and cured at $110^{\circ} \mathrm{C}$ for $10 \mathrm{~min}$. The discs were then suspended in a stirred 2 vol\% glutaraldehyde solution at $\mathrm{pH} 4.3$ at RT overnight. A solution of 2 wt. $\%$ chitosan was prepared with $0.2 \%$ acetic acid at RT and kept at $4^{\circ} \mathrm{C}$ overnight. Then, $1 \mathrm{ml}$ of each chitosan solution was cast over the implant discs at RT. Excess water was allowed to evaporate over 5-7 days to form a thin coating. The coated discs were sterilized using ultraviolet (UV) light for an hour, followed by soaking in ethanol $(70 \%)$ for $2 \mathrm{~h}$, and then washing twice with phosphate-buffered saline $(\mathrm{PBS})^{[15]}$. Before cell culture, one disc from each group was evaluated using scanning electron microscopy (SEM).

\section{Cell Culture}

Human mesenchymal stem cells (hMSC-TERT 20) were grown and maintained in a medium that consisted of DMEM (ATCC, Manassas, VA, USA) supplemented with penicillin-streptomycin solution $(10,000$ units $/ \mathrm{ml}$ penicillin $+10,000 \mu \mathrm{g} / \mathrm{ml}$ streptomycin $), 10 \%$ fetal bovine serum (FBS), and 1\% MEM nonessential amino acid solution under sterile cell culture conditions $\left(100 \%\right.$ humidity, $37^{\circ} \mathrm{C}, 95 \%$ air, and $5 \% \mathrm{CO} 2$ ). Passage 54 was used for the study, and following $80-$ $95 \%$ confluence, cells were collected by trypsinization using $0.25 \%$ trypsin-EDTA, washed, and counted with a hemocytometer. Later, all discs were placed in 48 individual wells. A total of $1 \times 10^{6}$ cells were plated with culture medium onto the implant discs and incubated for $24 \mathrm{~h}$ to facilitate adherence to the surface. The cells were grown in osteogenic medium containing $100 \mathrm{nmol} / \mathrm{L}$ dexamethasone, 10 $\mathrm{mmol} / \mathrm{L}$ sodium $\beta$-glycerophosphate pentahydrate, $50 \mathrm{~g} / \mathrm{ml} \mathrm{L}$-ascorbic acid, vitamin $\mathrm{C}$, cholecalciferol, and $(+)$ vitamin D3. The medium was changed every three days.

\section{Cell Morphology and Cell Viability Assays}

Scanning electron microscopy (SEM) and osteoblast adhesion were used to examine the samples 7 and 14 days after cell culture. Before SEM observation, the samples were washed three times with PBS. Next, the cells were fixed in $4 \% \mathrm{v} / \mathrm{v}$ glutaraldehyde at $4^{\circ} \mathrm{C}$ overnight. The cells were subsequently dehydrated in a series of ethanol solutions and then sputter-coated with gold for observation. For osteoblast adhesion, the samples were stained using rhodaminephalloidin staining. In brief, after cell incubation for $24 \mathrm{~h}, 4.0 \%$ paraformaldehyde was used to fix the samples for $15 \mathrm{~min}$. Then, the samples were blocked for $30 \mathrm{~min}$ using 1.0\% BSA and kept overnight at RT. One day later, 40,60-diamidino-2-phenylindole (DAPI, Sigma) was used to stain the specimens for $30 \mathrm{~min}$. The fluorescence images were obtained using a confocal microscope (a Zeiss LSM510 META confocal system, Zeiss Axiovert 200 microscope). Cell viability was evaluated using the Alamar blue assay. For each reaction, 10\% Alamar blue (AbD Serotec, Raleigh, NC, USA) was diluted to $100 \mu \mathrm{l}$ in DMEM and kept in the dark for $60 \mathrm{~min}$ at $37^{\circ} \mathrm{C}$. Readings were taken with a microplate reader (Synergy ${ }^{\mathrm{TM}} 2$ Multi-Mode Microplate Reader) at $590 \mathrm{~nm}$. Three readings were recorded for each sample at each time point.

RNA Isolation, $c D N A$, and Quantitative Real-Time-Polymerase Chain Reaction ( $q P C R)$

Total RNA was extracted on days 7 and 14 using the BIOFACT HiGene Total RNA Prep Kit (Biofact, Cat No RP101-100, Korea) as recommended. A spectrophotometer (Eppendorf-Biospectrometer basic) was used to determine the RNA concentration, and samples with purity ratios between 1.8 and 2.0 were used. Complementary DNA (cDNA) was prepared from $1 \mu \mathrm{g}$ of RNA using a FIREScript RT cDNA synthesis kit (Solis BioDyne, Cat No 06-15-00200). Amplification was completed using a 96-well reaction plate covered by optical adhesive covers in a total reaction volume of $20 \mu \mathrm{l}$.
qPCR reactions were used to assess gene expression using HOT FIREPol ${ }^{\circledR}$ EvaGreen ${ }^{\circledR}$ qPCR Supermix (Solis BioDyne, Cat No 0836-00008). B-actin served as the housekeeping gene for normalization. The same conditions were followed for performing all qPCR assays for each specific gene and were performed in triplicate $(\mathrm{n}=10$, duplicate independent experiments). The sense and antisense primers used in this experiment are listed in Table 1.

Table 1: Primers Sequence

\begin{tabular}{ccc}
\hline & Sequence Name & Description \\
\hline 1 & OSTEONECTIN F & 5' GAG GAA ACC GAA GAG G 3' \\
\hline 2 & OSTEONECTIN R & 5' GGG GTG TTG TTC TCA TCC AG 3' \\
\hline 3 & RUNX2 F-RO & 5' GTA GAT GGA CCT CGG GAA CC 3' \\
\hline 4 & RUNX2 R-RO & 5' GAG GCG GTC AGA GAA CAA AC 3' \\
\hline 5 & OSTEOCALCIN R-RO & 5' CTC ACA CAC CTC CCT G 3' \\
\hline 6 & OSTEOCALCIN F-RO & 5' GGC AGC GAG GTA GTG AAG AG 3' \\
\hline 7 & ACTB (Beta-actin) R & 5' ACATCTGCTGGAAGGTGGACA 3' \\
\hline 8 & ACTB (Beta-actin) F & 5' TCAAGATCATTGCTCCTCCTGAG 3' \\
\hline 9 & ALPL F & 5' GACGGACCCTCGCCAGTGCT 3' \\
\hline 10 & ALPL R & 5' AATCGACGTGGGTGGGAGGGG 3' \\
\hline
\end{tabular}

Measurement of Osteoblast Differentiation by Alkaline Phosphatase Activity

Alkaline phosphatase activity was measured using an ALP assay kit (BioVision Alkaline Phosphatase Activity Colorimetric Assay kit, Cat No K412-500ASSAY). Briefly, the culture medium was removed, and the samples were washed three times with PBS. The cells were then harvested from the wells by trypsinization using $0.25 \%$ trypsin-EDTA (1X). After centrifugation at $7500 \mathrm{rpm}$ for 5 min, the collected cell pellet was treated with the kit according to the company's protocol. The absorbance was measured at $405 \mathrm{~nm}$ in a microplate reader (Synergy ${ }^{\mathrm{TM}} 2$ Multi-Mode Microplate Reader).

\section{Ethical Approval}

This study was conducted as per the research protocols of King Saud University (KSU). Ethical committee approval was obtained from the Institutional Review Board (IRB; No. E-18-2850) and the College of Dentistry Research Center (CDRC No. PR 0074).

\section{Statistical Analysis}

IBM's Statistical Package for Social Sciences (SPSS 22; IBM Corp., NEW YORK, NY, USA) was used to analyze the data. The normality test was conducted using the Shapiro-Wilk test, and the data were normally distributed. Statistical significance of differences in gene expression between groups was determined using two-way ANOVA to test the interaction between groups and different genes. Then, one-way analysis of variance (ANOVA) followed by the Tukey post hoc test was performed. The results of the alkaline phosphatase and Alamar blue assays were analyzed using one-way analysis of variance (ANOVA) followed by the Tukey post hoc test. The measured data are expressed as the mean \pm standard deviation. Values were considered significant at $P \leq 0.05$.

\section{Results}

\section{Cell Morphology Results}

Before cell culture, the coating was investigated by SEM (Figure 1). The figure shows that the chitosan was homogeneous and free from 

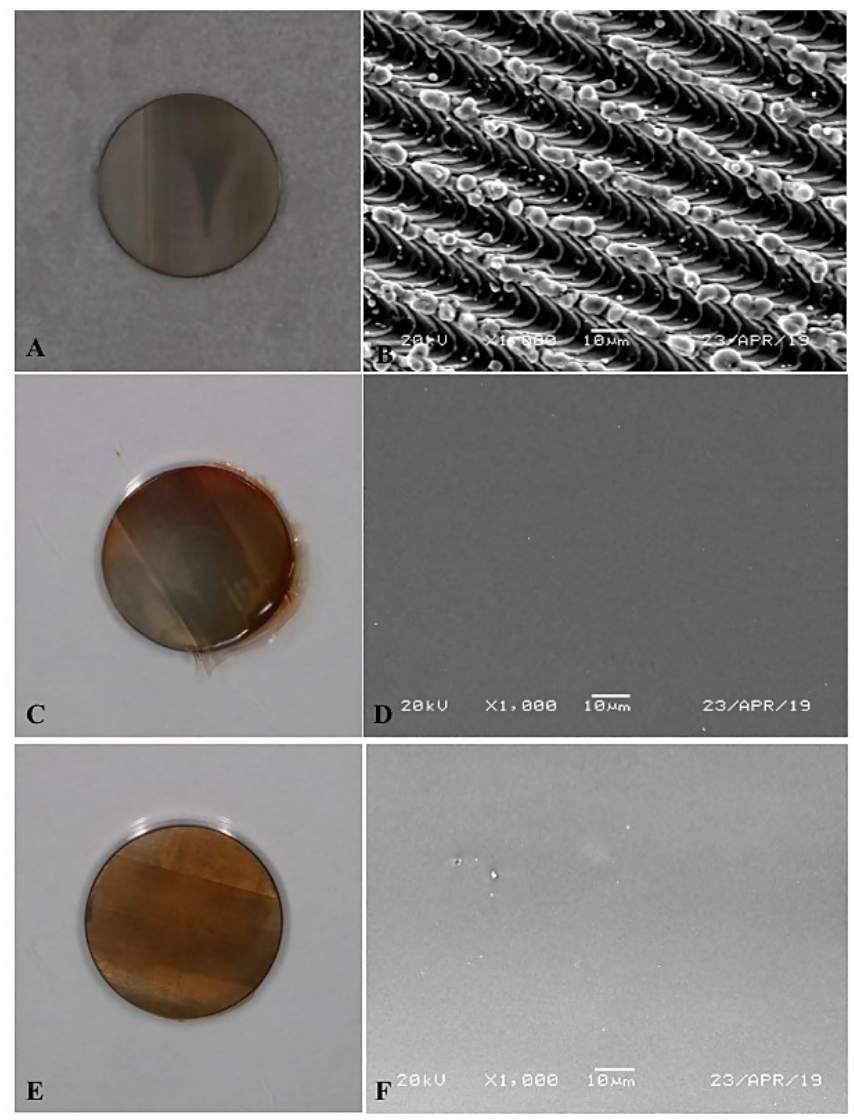

Figure 1: (a) Gross view of Laser lok (LL) control, (b) Under Scanning Electron Microscopy (SEM). (c) LL surface coated with 80 DDA, (d) Under SEM. (e) LL surface coated with $95 D D A$, (f) under SEM.

any cracks or fissures. On the other hand, the Laser-Lok control surface presented a honeycomb pattern with small pores. This structure was composed of serial microchannels, which included a repeating nanostructure. After cell culture, SEM showed a clear layer of osteoblasts adhered to samples on days 7 and 14 (Figure 2).

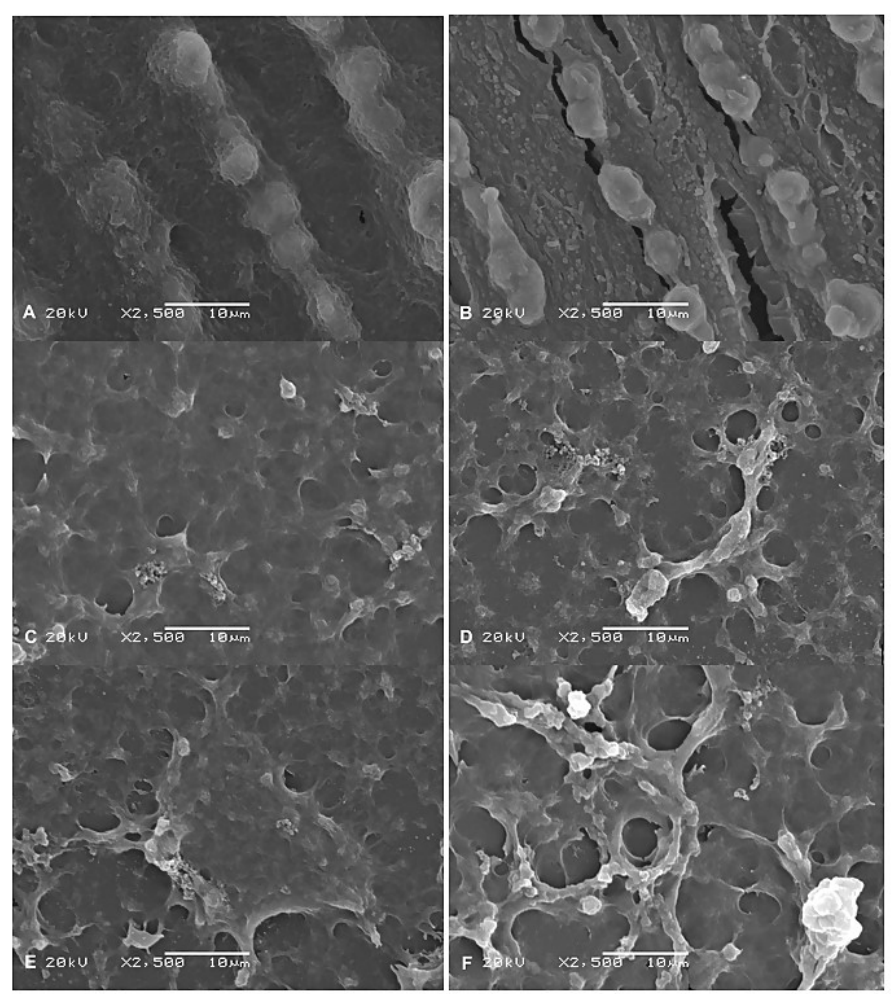

Figure 2: Scanning Electron Microscopy (SEM) images. (A) Laser lok (LL) control at day 7 (B) at day 14. (C) LL surface coated with 80 DDA at day 7 (D) at day 14. (E) LL surface coated with 95 DDA at day 7. (F) At day 14. 2500 $\times$ magnification.
The chitosan-coated samples showed a high degree of cell spreading and proper attachment of hMSCs to the surface on day 7 compared to the control group. The cells were more flattened and merged to the underlying surface in the group coated with 95 DDA. For the LL control, the cells were guided by the direction of the grooves in an organized manner. Moreover, the cells preferentially attached and formed bridges inside the holey structure created by laser ablation. On day 14, an amount of mineralization can be seen on all surfaces with a noticeable sheet of cells covering the chitosan surfaces. For osteoblast adhesion, all samples showed proper attachment and consistent growth after $24 \mathrm{~h}$ of incubation. The cell density area of the chitosan-coated samples was higher compared to the control. However, the osteoblasts were flattened, elongated, and aligned with the grooves obtained by laser ablation, even for the coated samples. Nuclei, which appeared blue, were multi and aligned with the grooves as well (Figure 3).
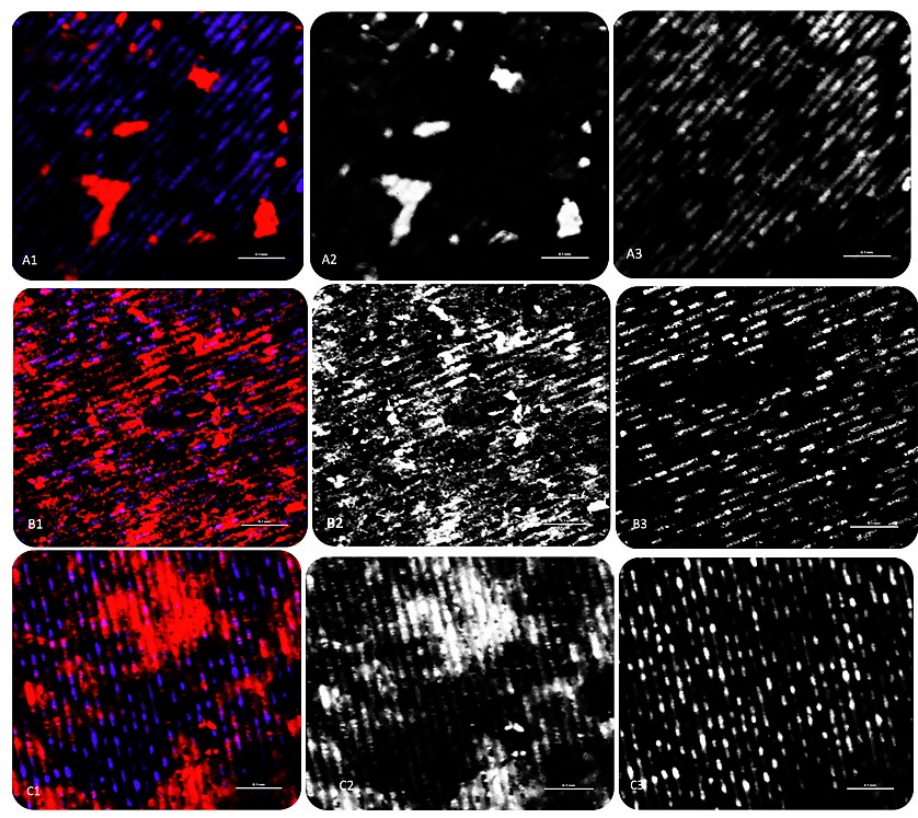

Figure 3: Images of cell morphology. (A1) for LL control as all. (A2) With Phalloidin for actin filaments. (A3) Nuclei stained with DAPI. (B1) for LL 80 as all. (B2) With Phalloidin for actin filaments. (B3) Nuclei stained with DAPI. (C1) for LL 95 as all. (C2) with Phalloidin for actin filaments. (C3) Nuclei stained with DAPI.

\section{Cell Viability Results}

The Alamar blue assay indicated no significant difference between the groups except for LL 80, which was lower at both periods compared to the other groups (Figure 4).

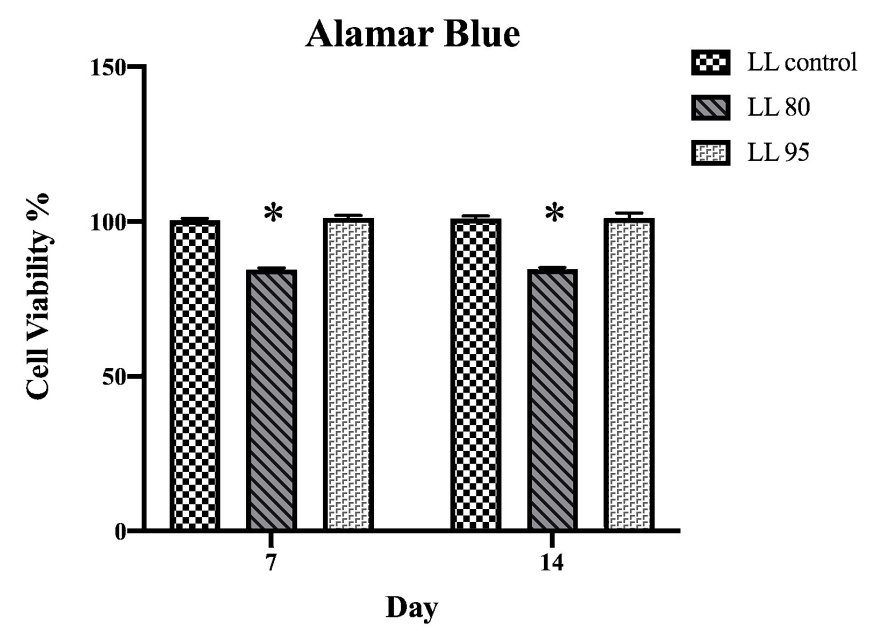

Figure 4: Alamar blue quantification assessed at 7 and 14 days of culture. ${ }^{*} p<0.05$. 


\section{Quantitative Real-Time-Polymerase Chain Reaction ( $q P C R$ ) Results}

On day 7, the expression levels of ALP, osteocalcin (OC), osteonectin (ON), and Runx2 were significantly higher on the discs coated with 95 DDA $(\mathrm{p}<0.05)$ (Figure 5). On day 7, ALP and Runx2 showed significantly higher expression in all groups. In contrast, osteocalcin (OC) and osteonectin (ON) displayed lower expression on day 7. On day 14, the highest expression of all genes was found to be associated with LL 95. All gene expression levels increased from day 7 to day 14 except for Runx2, which decreased from day 7 to day 14 .
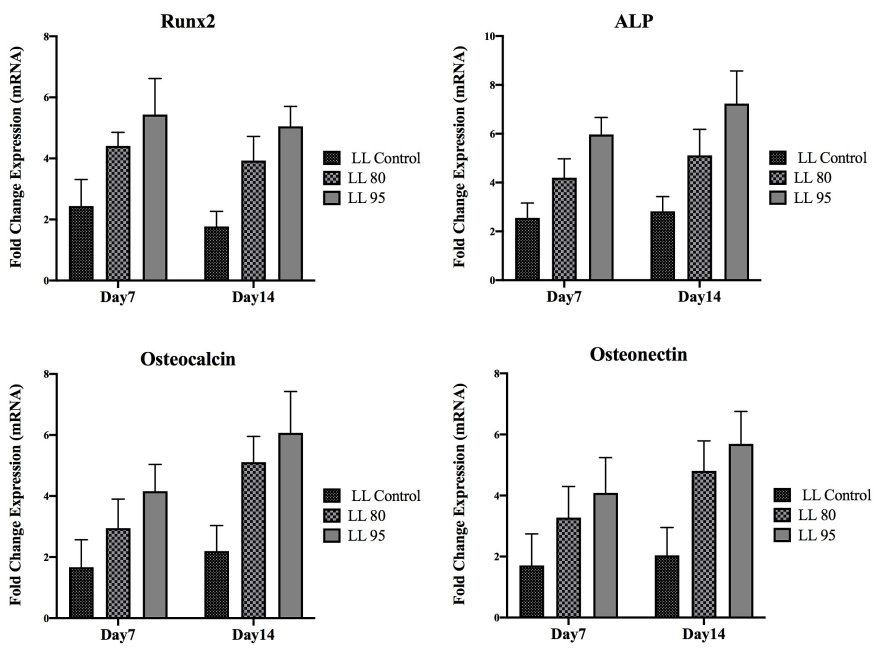

Figure 5: Osteoblast gene expression at 7 and 14 days from cell culture.

\section{Alkaline Phosphatase Activity Results}

Generally, high ALP activity was found for the cells grown on chitosan-coated implant discs compared to the ALP activity of the noncoated discs (Figure 6). On days 7 and 14, ALP expression was significantly higher from the 95 DDA-coated implant discs $(\mathrm{p}<$ 0.05 ). The results showed that for all groups, ALP activity increased from day 7 to 14 .

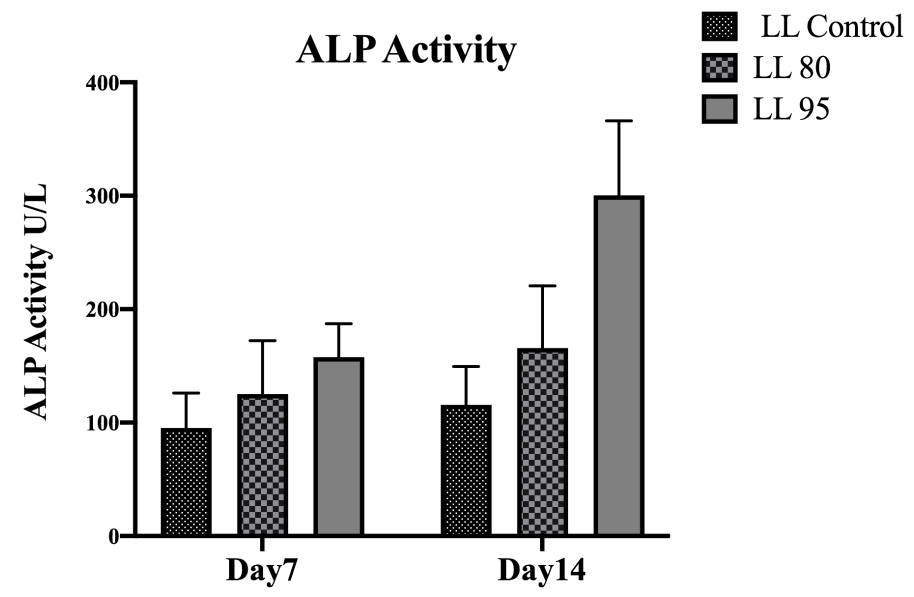

Figure 6: Alkaline phosphatase activity at 7 and 14 days of cell culture.

\section{Discussion}

Chitosan is extensively used for bone regeneration methods due to its biocompatibility, reduction in inflammation, and tissue growth ${ }^{[18]}$. Therefore, commercial LL discs were coated with different DDAs of chitosan (80 and 95) to examine how the cells would respond. Previous studies showed that chitosan could chemically attach to the underlying surfaces through their $\mathrm{NH} 2$ group, which occurred through their saline-glutaraldehyde molecules and accounted for the yellowish tint on all the coatings ${ }^{[19,20]}$. Analysis of cell morphology was evaluated using SEM and confocal microscopy. In general, all samples allowed cell adherence, growth, and differentiation $24 \mathrm{~h}, 7$ days, and 14 days from cell culture. In the LL control, the cells aligned along the grooves in a phenomenon called contact guidance in which the cells follow the direction of the organized texture ${ }^{[21,22]}$. This design pattern was produced by a pulsed EXCIMER laser that created consistent channels with dimensions of 8 microns of parallel grooves. These microchannels were highly compatible and optimally sized to allow the attachment and organization of MSCs with an average diameter of $15 \sim 30 \mu \mathrm{m}[7,23,24]$. For LL 95 and LL 80, dense flattened osteoblasts approximating each other can be seen on the top of the surface. Interestingly, the osteoblasts still followed the direction of the groove, although the surface was covered with chitosan. This indicates that the coating somehow followed the honeycomb pattern in a homogenous way. The response of the cells to the surface coating in terms of cytotoxicity was evaluated using Alamar blue. All groups were biocompatible and noncytotoxic 7 and 14 days after cell culture. Moreover, no significant differences were seen between groups except for LL 80 . However, although the cell viability was lower for LL 80 , complete cell confluence and adherence were still observed after 7 and 14 days. Additionally, according to the International Organization ISO10993-5, if the cell viability is not $<70 \%$, then the material does not have cytotoxic potential ${ }^{[25]}$. Osteoblast differentiation was examined using molecular assays 7 and 14 days after cell culture. Quantitative RTPCR for osteogenic markers, including Runx2, ALP, osteocalcin, and osteonectin, confirmed the differentiation of cells, with the highest gene expression observed on the chitosan-coated groups, especially the 95 DDA group. Initial studies showed that chitosan with high degrees of deacetylation comprises various amino groups, which help in bonding to the implant surface ${ }^{[26]}$. As the number of positively charged amino groups increases, the net positive charge on the coated samples increases. Consequently, the coating will have a higher affinity for negatively charged cells and growth factors, which correlates with increased cell attachment and differentiation $^{[27-29]}$. Runx2 has been identified to be the first transcription factor for bone development and is needed for the initiation of the osteoblast lineage ${ }^{[30,31]}$.

The expression of Runx 2 would normally be high beginning at one week from cell culture and then decrease with osteoblast maturation and bone mineralization ${ }^{[32,33]}$. In agreement with these findings, the present study indicated that Runx2 expression was higher in the early phase of osteoblast differentiation compared to day 14. As time passed, the mature osteoblast cells did not show a significant quantity of Runx2. However, the maximum expression level of Runx2 was observed in the chitosan-coated groups compared to that of the control group, and the highest expression was associated with 95 DDA. As Runx2 promotes osteoblastogenesis, committed preosteoblasts start to differentiate and be identified because of their ALP expression, which is one of the earliest signs of the osteoblast phenotype ${ }^{[34]}$. It was observed that ALP level expression increases after two days poststimulation with steady increases as a result of progressive osteoblast differentiation (up to 14 days) ${ }^{[35,36]}$. In the present study, after 7 days, cells cultured on discs coated with chitosan had a higher level of ALP mRNA compared to the level of the noncoated group. Similar to Runx2, the highest level was found to be associated with 95 DDA. On day 14, the expression of ALP increased for all groups and was significantly higher in LL 95. Osteocalcin and osteonectin are good markers of mature osteoblast cells and are highly specific for bone mineralization ${ }^{[34,36,37]}$. These genes were investigated in our study, and our results demonstrated that their expression increased from day 7 to day 14 and was greater on discs coated with LL 95.

Concerning the different DDAs, previous studies have shown that high DDA polymers in the range of $80-95 \%$ tend to have tighter chain packing and increased crystallinity, which limits enzymatic attack to the chain and thus decreases the degradation rate ${ }^{[19,38]}$. 
Additionally, chitosan with a high DDA (87-95\%) is known to support cell growth and differentiation. Moreover, calcium deposition was greater on chitosan samples compared to the control from day 3 until day $28^{[39,40]}$. Based on these results, it was found that 95 DDA was superior for osteoblast differentiation than 80 DDA.

Computer-controlled laser ablation techniques formed lasermodified surfaces. These unique structures were the only surface treatments that can achieve connective tissue attachment and hard tissue formation ${ }^{[23]}$. To the extent of the researchers' knowledge, this is the first work to examine the chitosan-coated LL surface. However, this study has some limitations in terms of the small sample size and short time frame (only 14 days). Additionally, the study's scope was to only examine the biological potential of the chitosan-laser surface combination. Therefore, additional studies are needed with a large sample to clarify the influence of different DDAs on the bonding strength and degradation rate of chitosan as a coating material.

\section{Conclusions}

This study found that a high DDA of chitosan increases biomineralization and osteoblast cell formation. Our results provide deep insight into the direct effect of chitosan with two DDA coating materials for laser-treated surfaces, and these findings encourage future studies to enhance implant osseointegration.

\section{References}

1. Albrektsson T, Brånemark PI, Hansson HA, Lindström J. Osseointegrated titanium implants. Requirements for ensuring a long-lasting, direct bone-to-implant anchorage in man. Acta Orthop Scand. 1981;52(2):155-70

2. Chrcanovic BR, Kisch J, Albrektsson T, Wennerberg A. Factors Influencing Early Dental Implant Failures. J Dent Res. 2016 ;95(9):995-1002

3. Soskolne WA, Cohen S, Sennerby L, Wennerberg A, Shapira L. The effect of titanium surface roughness on the adhesion of monocytes and their secretion of TNF-alpha and PGE2. Clin Oral Implants Res. 2002;13(1):86-93.

4. Junker R, Dimakis A, Thoneick M, Jansen JA. Effects of implant surface coatings and composition on bone integration: a systematic review. Clin Oral Implants Res. 2009;20 Suppl 4:185206.

5. Deppe H, Wolff C, Bauer F, Ruthenberg R, Sculean A, Mücke T. Dental implant surfaces after insertion in bone: an in vitro study in four commercial implant systems. Clin Oral Investig. 2018;22(3):1593-1600.

6. Gotfredsen K, Berglundh T, Lindhe J. Anchorage of titanium implants with different surface characteristics: an experimental study in rabbits. Clin Implant Dent Relat Res. 2000;2(3):120-128.

7. Nevins M, Nevins ML, Camelo M, Boyesen JL, Kim DM. Human histologic evidence of a connective tissue attachment to a dental implant. Int J Periodontics Restorative Dent. 2008;28(2):111-121.

8. Smeets R, Stadlinger B, Schwarz F, et al. Impact of Dental Implant Surface Modifications on Osseointegration. Biomed Res Int. 2016;2016:6285620.

9. Elieh-Ali-Komi D, Hamblin MR. Chitin and Chitosan: Production and Application of Versatile Biomedical Nanomaterials. Int J Adv Res (Indore). 2016;4(3):411-427.

10. Rao MS, Muñoz J, Stevens WF. Critical factors in chitin production by fermentation of shrimp biowaste. Appl Microbiol Biotechnol. 2000;54(6):808-813.

11. Husain S, Al-Samadani KH, Najeeb S, Zafar MS, Khurshid Z, Zohaib S, Qasim SB. Chitosan Biomaterials for Current and Potential Dental Applications. Materials (Basel). 2017;10(6):602.

12. Konovalova MV, Markov PA, Durnev EA, Kurek DV, Popov SV, Varlamov VP. Preparation and biocompatibility evaluation of pectin and chitosan cryogels for biomedical application. J Biomed Mater Res A. 2017;105(2):547-556.
13. Yuan Y, Chesnutt BM, Haggard WO, Bumgardner JD. Deacetylation of Chitosan: Material Characterization and in vitro Evaluation via Albumin Adsorption and Pre-Osteoblastic Cell Cultures. Materials (Basel). 2011:4(8):1399-1416.

14. Ueno H, Mori T, Fujinaga T. Topical formulations and wound healing applications of chitosan. Adv Drug Deliv Rev. 2001;52(2):105-115.

15. Govindharajulu JP, Chen X, Li Y, Rodriguez-Cabello JC, Battacharya M, Aparicio C. Chitosan-Recombinamer Layer-byLayer Coatings for Multifunctional Implants. Int J Mol Sci. 2017;18(2):369.

16. Li X, Ma XY, Feng YF, Ma ZS, Wang J, Ma TC, Qi W, Lei W, Wang L. Osseointegration of chitosan coated porous titanium alloy implant by reactive oxygen species-mediated activation of the PI3K/AKT pathway under diabetic conditions. Biomaterials. 2015;36:44-54.

17. Bumgardner JD, Wiser R, Gerard PD, et al. Chitosan: potential use as a bioactive coating for orthopaedic and craniofacial/dental implants. J Biomater Sci Polym Ed. 2003;14(5):423-438

18. Cheung RC, Ng TB, Wong JH, Chan WY. Chitosan: An Update on Potential Biomedical and Pharmaceutical Applications. Mar Drugs. 2015;13(8):5156-5186.

19. Yuan Y, Chesnutt BM, Wright L, Haggard WO, Bumgardner JD. Mechanical property, degradation rate, and bone cell growth of chitosan coated titanium influenced by degree of deacetylation of chitosan. J Biomed Mater Res B Appl Biomater. 2008;86(1):245252.

20. Moutzouri AG, Athanassiou GM. Attachment, spreading, and adhesion strength of human bone marrow cells on chitosan. Ann Biomed Eng. 2011;39(2):730-741.

21. Soboyejo WO, Nemetski B, Allameh S, Marcantonio N, Mercer C, Ricci J. Interactions between MC3T3-E1 cells and textured Ti6Al4V surfaces. J Biomed Mater Res. 2002;62(1):56-72.

22. Ricci JL, Grew JC, Alexander H. Connective-tissue responses to defined biomaterial surfaces. I. Growth of rat fibroblast and bone marrow cell colonies on microgrooved substrates. J Biomed Mater Res A. 2008:85(2):313-325.

23. Esfahanizadeh N, Motalebi S, Daneshparvar N, Akhoundi N, Bonakdar S. Morphology, proliferation, and gene expression of gingival fibroblasts on Laser-Lok, titanium, and zirconia surfaces. Lasers Med Sci. 2016;31(5):863-873.

24. Krueger TEG, Thorek DLJ, Denmeade SR, Isaacs JT, Brennen WN. Concise Review: Mesenchymal Stem Cell-Based Drug Delivery: The Good, the Bad, the Ugly, and the Promise. Stem Cells Transl Med. 2018;7(9):651-663.

25. ISO 10993-5 I. Biological Evaluation of Medical Devices. Part 5: Tests for in Vitro Cytotoxicity 2009.

26. Bumgardner JD, Wiser R, Elder SH, Jouett R, Yang Y, Ong JL. Contact angle, protein adsorption and osteoblast precursor cell attachment to chitosan coatings bonded to titanium. J Biomater Sci Polym Ed. 2003;14(12):1401-1409.

27. Fakhry A, Schneider GB, Zaharias R, Senel S. Chitosan supports the initial attachment and spreading of osteoblasts preferentially over fibroblasts. Biomaterials. 2004;25(11):2075-2079.

28. Hamilton V, Yuan Y, Rigney DA, Chesnutt BM, Puckett AD, Ong JL, Yang Y, Haggard WO, Elder SH, Bumgardner JD. Bone cell attachment and growth on well-characterized chitosan films. Polymer International 2007; 56: 641-647.

29. Oryan A, Sahvieh S. Effectiveness of chitosan scaffold in skin, bone and cartilage healing. Int J Biol Macromol. 2017;104(Pt A):1003-1011.

30. Komori T, Yagi H, Nomura S, Yamaguchi A, Sasaki K, Deguchi K, Shimizu Y, Bronson RT, Gao YH, Inada M, Sato M, Okamoto R, Kitamura Y, Yoshiki S, Kishimoto T. Targeted disruption of Cbfa1 results in a complete lack of bone formation owing to maturational arrest of osteoblasts. Cell. 1997;89(5):755-764.

31. Otto F, Thornell AP, Crompton T, Denzel A, Gilmour KC, Rosewell IR, Stamp GW, Beddington RS, Mundlos S, Olsen BR, Selby PB, Owen MJ. Cbfa1, a candidate gene for cleidocranial dysplasia syndrome, is essential for osteoblast differentiation and bone development. Cell. 1997;89(5):765-71.

32. Komori T. Regulation of osteoblast differentiation by Runx2. Adv Exp Med Biol. 2010;658:43-49. 
33. Maruyama Z, Yoshida CA, Furuichi T, Amizuka N, Ito M, Fukuyama R, Miyazaki T, Kitaura H, Nakamura K, Fujita T, Kanatani N, Moriishi T, Yamana K, Liu W, Kawaguchi H, Nakamura K, Komori T. Runx2 determines bone maturity and turnover rate in postnatal bone development and is involved in bone loss in estrogen deficiency. Dev Dyn. 2007;236(7):187690.

34. Stein GS, Lian JB. Molecular mechanisms mediating proliferation/differentiation interrelationships during progressive development of the osteoblast phenotype. Endocr Rev. 1993;14(4):424-442.

35. Shui C, Spelsberg TC, Riggs BL, Khosla S. Changes in Runx2/Cbfa1 expression and activity during osteoblastic differentiation of human bone marrow stromal cells. J Bone Miner Res. 2003;18(2):213-221.

36. Choi MH, Noh WC, Park JW, Lee JM, Suh JY. Gene expression pattern during osteogenic differentiation of human periodontal ligament cells in vitro. $\mathrm{J}$ Periodontal Implant Sci. 2011;41(4):167-175.
37. Thorwarth M, Rupprecht S, Falk S, Felszeghy E, Wiltfang J, Schlegel KA. Expression of bone matrix proteins during de novo bone formation using a bovine collagen and platelet-rich plasma (prp)--an immunohistochemical analysis. Biomaterials. 2005;26(15):2575-2584.

38. Leedy MR, Martin HJ, Norowski PA, Jennings JA, Haggard WO, Bumgardner JD. Chitosan for Biomaterials II. Eds: Jayakumar R, Prabaharan M, Muzzarelli RAA. Springer-Verlag Berlin Heidelberg; c2011;p129-165.

39. Leedy MR, Jennings JA, Haggard WO, Bumgardner JD. Effects of VEGF-loaded chitosan coatings. J Biomed Mater Res A. 2014;102(3):752-759

40. Abuelreich S, Manikandan M, Aldahmash A, Alfayez M, Al Rez MF, Fouad H, Hashem M, Ansari SG, Al-Jassir FF, Mahmood A. Human Bone Marrow MSCs form Cartilage and Mineralized Tissue on Chitosan/Polycaprolactone (CS/PCL) Combined Nanofibrous Scaffolds. Journal of Nanoscience and Nanotechnology 2017; 17: 1771-1778.

\section{Abbreviations}

$\begin{array}{ll}\text { DDA } & \text { : Degrees of Deacetylation } \\ \text { FBS } & \text { : Fetal Bovine Serum } \\ \text { hMSC-TERT 20 } & \text { : Human Bone Marrow-Derived Mesenchymal Stem Cells } \\ \text { MSCs } & \text { : Mesenchymal Stem Cells } \\ \text { LL } 80 & \text { : Laser Lok coated with } 80 \text { DDA } \\ \text { LL 95 } & \text { : Laser Lok coated with 95 DDA } \\ \text { LL control } & \text { : Laser Lok without coating } \\ \text { RT } & \text { : Room Temperature }\end{array}$

\section{Potential Conflicts of Interests}

\section{None}

\section{Sponsors/Grants}

This research project was funded by Prince Naif Bin Abdulaziz Health Research Center, King Saud University Medical City, Riyadh. Also, the hMSC-TERT20 line was kindly provided by the Molecular and Cell Biology Laboratory, College of Dentistry in collaboration with the Prince Naif Bin Abdulaziz Health Research Center, Riyadh, KSA.

\section{Acknowledgement}

The author is thankful to all the associated personnel, who contributed for this study by any means. Also, we thank Biohorizon for providing us with the implant discs.

\section{Corresponding Author}

Khalid S Al-Hamdan, Department of Periodontics and Community Dentistry; College of Dentistry, PO Box;7669, King Saud University, unite-1/12372 Riyadh, Saudi Arabia. Email : khalidh1@ksu.edu.sa / perio.alhamdan@gmail.com 